\title{
IMPACT OF INFORMATION SERVICES USING MEDIA FILM TO STUDENT MOTIVATION LEARNING AT SMA NEGERI 1 RAMAN UTARA, LAMPUNG TIMUR
}

\author{
Septazema Suciana \& Nurul Atieka
}

Universitas Muhammadiyah Metro

\begin{abstract}
One of the factors that can influence student learning is the motivation to learn. Students' motivation can be built with an understanding to students about the importance of learning how to learn effectively, and how to overcome learning problems. Departing from this, the research problem is formulated as follows: Is there any influence of information services on the students motivation ?. The aim of research to determine the effect of information services on the students motivation. The study design was one group pretest-posttest design. Subjects numbered 20 students. To determine the study subjects used the technique Proportionate Stratified Random Sampling.Hasil hypothesis test showed the value of $t=8.75>$ 1.729. The conclusion of the study is an information service that executed can affect motivation. Therefore, it is advisable to guidance and counseling teachers use information services by using the medium of film, so that the services effectively organized and able to enhance students' motivation.
\end{abstract}

Keyword: Information Services, Motivation, Students

\section{PENDAHULUAN}

Usaha pencapaian prestasi
yang maksimal oleh siswa
dipengaruhi oleh beberapa faktor,
baik dari diri siswa ataupun faktor
yang berasal dari luar diri siswa.
Faktor tersebut memiliki peran yang
sangat besar dalam proses
pencapaian hasil belajar yang
dilakukan siswa. Proses belajar yang
dilakukan oleh siswa terkait dengan

kondisi eksternal dan internal dari siswa itu sendiri. Kondisi internal yang mempegaruhi seperti intelegiensi, kondisi fisik, mental, motivasi, persepsi dan juga terkait dengan bakat dan minat dari siswa. Sedangkan kondisi yang mempengaruhi proses belajar daari aspek luar diri individu juga cukup banyak, diantaranya kondisi budaya dan lingkungan sosial siswa, kondis 
keluarga, sarana prasarana belajar, kondisi sekolah yang didalamnya mencakup pendidik, regulasi pendidikan, dan juga kurikulum.

$$
\text { Berbagai faktor yang }
$$

mempengaruhi proses dan hasil belajar siswa memiliki keterkaitan antara satu faktor dengan faktor lainnya. Motivasi belajar sebagai faktor pendorong yang utama dalam terjadinya proses belajar pada siswa terkait erat dengan terhadap faktor belajar lainnya. Ketika anak berada pada lingkungan yang kondusif untuk belajar, penerimaan dan pola pendidikan yang baik dari guru, serta adanya dukungan yang penuh dari orangtua untuk melakukan proses belajar, maka dalam diri siswa akan terbangun motivasi yang kuat untuk belajar.

Motivasi mempunyai peran dan pengaruh yang cukup besar terhadap proses dan hasil belajar. Motivasi merupakan tenaga dari dalam yang menyebabkan seseorang untuk berbuat sesuatu dan melakukan kegiatan belajar.. Hal tersebut diterangkan pula oleh Freud (dalam Sardiman, 2010) yaitu ciriciri motivasi belajar yang ada dalam diri seseorang yaitu: tekun menghadapi tugas, ulet menghadapi kesulitan (tidak mudah putus asa), menunjukan minat terhadap berbagai masalah, lebih senang bekerja mandiri, cepat bosan pada tugastugas yang rutin, dapat mempertahankan pendapatnya, tidak mudah melepaskan hal yang diyakini, dan senang mencari dan memecahkan soal-soal.

Salah satu variabel yang mempengaruhi kondisi pembelajaran efektif adalah adanya motivasi siswa dalam belajar. Menurut Mc. Donald (dalam Hamalik, 2011) "motivasi adalah perubahan energi dalam diri (pribadi) seseorang yang ditandai dengan timbulnya perasaan dan reaksi untuk mencapai tujuan". Motivasi merupakan suatu kondisi dalam diri seseorang yang relatif menetap. Motivasi besar sekali pengaruhnya terhadap belajar, sebab dengan motivasi seseorang akan melakukan sesuatu yang diinginkannya. Sebaliknya tanpa motivasi, seseorang tidak mungkin melakukan sesuatu. Semakin tinggi motivasi yang dimiliki siswa, maka siswa akan lebih terdorong untuk mengikuti pembelajaran dengan baik. Jadi motivasi akan senantiasa 
menentukan usaha belajar bagi para siswa.

Fenomena yang terjadi dalam proses belajar dan pembelajaran di sekolah, masih banyak siswa yang rendah motivasi belajarnya. Masalah tersebut terlihat dari tingkat kedisiplinan yang rendah dalam belajarnya, cepat jenuh saat proses belajar dikelas, dan juga malas secara mandiri mengerjakan tugas sekolah. Kondisi tersebut juga dialami oleh beberapa siswa SMA Negeri 1 Raman Utara pada tahun ajaran 2013/2014.. Dari hasil penyebaran angket yang peneliti lakukan pada tanggal 25-29 Maret 2014 terhadap 61 siswa, diperoleh data sebagai berikut:

\begin{tabular}{|l|l|c|c|}
\hline No & \multicolumn{1}{|c|}{ Faktor yang diamati } & Prosentasi & Kategori \\
\hline 1. & Tekun dalam menghadapi tugas & $30 \%$ & Rendah \\
\hline 2 & Ulet dalam menyelesaikan tugas & $40 \%$ & Rendah \\
\hline 3 & Minat terhadap berbagai macam masalah belajar & $40 \%$ & Rendah \\
\hline 4 & Mandiri dalam belajar & $50 \%$ & Sedang \\
\hline 5 & Cepat bosan pada tugas-tugas yang rutin & $50 \%$ & Sedang \\
\hline 6 & Dapat mempertahankan pendapat & $50 \%$ & Sedang \\
\hline 7 & Kukuh terhadap hal yang diyakini & $50 \%$ & Sedang \\
\hline 8 & Senang mencari dan memecahkan soal-soal. & $40 \%$ & Rendah \\
\hline
\end{tabular}

Penyebab rendahnya motivasi belajar tersebut diduga karena: siswa kurang tertarik dengan materi yang disampaikan, banyak siswa yang malu bertanya kepada guru, siswa belum memahami pentingnya motivasi dalam belajar, belum memahami bahwa untuk mencapai kesuksesan seseorang harus tekun, ulet, punya minat yang besar, dapat mandiri dalam belajar, senang dengan hal baru, mampu mempertahankan pendapat, kukuh dalam keyakinan, dan senang dengan tantangan yang kesemuaannya itu merupakan ciri-ciri motivasi belajar yang tinggi.

Guru Bimbingan dan Konseling memiliki peran dan dapat memberikan solusi untuk meningkatkan motivasi belajar siswa. Dalam Bimbingan dan Konseling terdapat beberapa jenis layanan yang dapat digunakan untuk memahami, memelihara, mencegah dan mengentaskan masalah siswa, termasuk dalam usaha meningkatkan motivasi belajar siswa. Salah satu 
layanan bimbingan dan konseling yang bisa dimanfaatkan untuk meningkatkan motivasi belajar siswa adalah layanan informasi.

Layanan informasi adalah layanan yang memungkinan siswa untuk menerima, memahami, dan dibekali berbagai pengetahuan dan pemahaman tentang infomasi yang mereka perlukan. layanan informasi dapat digunakan untuk memotivasi siswa supaya siswa dapat mengembangkan motivasi belajar di sekolah, siswa dapat mempersiapkan diri sebaik mungkin dalam menentukan cita-cita dimasa yang akan datang dan siswa dapat memotivasi belajar dengan efektif. Menurut Prayitno (2004:2) "layanan informasi berusaha memenuhi kekurangan individu akan informasi yang mereka perlukan, informasi yang diperoleh kemudian diolah dan digunakan individu untuk kepentingan hidup dan perkembangannya".

Layanan informasi dengan menggunakan media diperlukan agar siswa dapat lebih memahami materi layanan yang diberikan. Media yang dapat dipadukan dalam layanan informasi adalah media film, dimana film tersebut berisikan informasi tentang cara meningkatkan motivasi belajar, mengurangi rasa malas belajar dan cara belajar yang efektif dan efisien yang disajikan dengan contoh dalam bentuk cerita/contoh yang lebih realisitis. Penggunaan media yang tepat dan menarik oleh guru untuk membangkitkan motivasi siswa dalam pemberian layanan, sangatlah penting.

Media adalah sesuatu yang dapat merangsang pikiran, perasaan, dan kemauan siswa sehingga dapat mendorong terciptanya proses layanan yang kondusif. Media merupakan alat bantu dalam penyampaian materi layanan yang dapat membantu meningkatkan motivasi siswa dalam mengikuti layanan. Dengan menggunakan media yang sesuai, bervariasi, dan menarik proses bimbingan dan konseling jadi lebih terbantu dan lebih mudah. Menurut Rohani (1997:3) "Media adalah segala sesuatu yang dapat diindra yang berfungsi sebagai perantara/sarana/alat untuk proses komunikasi (proses belajar mengajar)". Media yang menarik 
untuk meningkatkan motivasi belajar adalah media film.

Film merupakan salah satu media selain media gambar yang bisa mempengaruhi penontonnya. Film merupakan bentuk produk kebudayaan. Hal tersebut sesuai dengan kekuatan film dalam merepresentasikan kehidupan sehingga mampu memuat nilai budaya masyarakat. Menurut Satrio (2005) film adalah media komunikasi yang bersifat audio visual untuk menyampaikan suatu pesan kepada sekelompok orang yang berkumpul disuatu tempat tertentu".

Film mempunyai kekuatan mendalam untuk memberikan pengaruh secara psikologis. Sadar atau tidak, setelah menonton film akan ada kesan yang tertanam dalam memori orang tersebut. Kesan tersebut akan mengendap dari dalam diri orang yang bersangkutan, sampai akhirnya memberikan pengaruh kepada pola atau sikap mereka. Dengan menggunakan media film diharapkan siswa dapat meningkatkan motivasi belajarnya, siswa menjadi lebih semangat, berpartisipasi aktif dan tidak ada rasa malas dalam mengikuti layanan.

\section{METODE PENELITIAN}

Penelitian yang dilaksanakan adalah penelitian eksperimental dengan desain The One Group Pretest-Posttest Design. Perlakukan yang diberikan kepada subjek penelitian adalah layanan informasi menggunakan media film. Populasi penelitian adalah siswa kelas XI IPA SMA Negeri 1 Raman Utara yang mangalami motivasi belajar rendah. Subjek penelitian berjumlah 20 orang yang dipilih secara random dengan teknik sampling Proportionate Stratified Random Sampling. Instrumen yang digunakan untuk mengumpulkan data adalah angket, kemudian data yang terkumpul dianalisis dengan menggunakan uji t (student $t$ ).

Rancangan penelitian yang digunakan seperti pada gambar berikut:

Rancangan penelitian ini dapat digambarkan sebagai berikut : 


\section{Hasil Penelitian}

\section{a. Deskripsi Pretest Motivasi}

\section{Belajar Siswa}

Sebelum dilakukan

Gambar 1. Rancangan Penelitian The One Group Pretest-Posttest Design

perlakuan layanan informasi

Keterangan :

$\begin{array}{llll}\mathrm{O}_{1} & : & \text { Pre-test } & \\ \mathrm{O}_{2} & : & \text { Post-test } \\ \mathrm{X} & : & \text { Perlakuan layanan }\end{array}$

informasi menggunakan media film( 3x Layanan)

HASIL DAN PEMBAHASAN dengan media film, siswa yang terpilih menjadi subjek penelitian dilakukan pretest untuk mengetahui kondisi awal motivasi belajarnya. Hasil pretest disajikan berikut ini:

Tabel 1. Data Pretest Motivasi Belajar

\begin{tabular}{|ccl|}
\hline Subjek Penelitian & Jumlah skor & \multicolumn{1}{c|}{ Kategori } \\
\hline 1. Sita & 79 & Kurang \\
2. Neily & 103 & Sedang \\
3. Revi & 52 & Sangat Kurang \\
4. Galuh & 79 & Kurang \\
5. Resti & 108 & Sedang \\
6. Putri & 85 & Sedang \\
7. Helda & 102 & Sedang \\
8. Aulia & 52 & Sangat Kurang \\
9. Ahmad & 79 & Kurang \\
10. Ayu & 108 & Sedang \\
11. Ridwan & 83 & Kurang \\
12. Berlian & 82 & Kurang \\
13. Budi & 52 & Sangat Kurang \\
14. Isma & 78 & Kurang \\
15. Rani & 107 & Sedang \\
16. Deni & 77 & Kurang \\
17. Edi & 114 & Tinggi \\
18. Azimah & 83 & Kurang \\
19. Nensi & 90 & Sedang \\
20. Tika & 100 & Sedang \\
\hline N $=20$ & $2=17$ & \\
& $\mathrm{X}_{1}=\underline{713}=\frac{13}{20}=\underline{85,65}$ & \\
\hline
\end{tabular}


Berdasarkan tabel di atas, diketahui bahwa motivasi belajar siswa pada saat pretest adalah sebanyak 3 siswa berada pada sangat kurang, 8 siswa berada pada kategori kurang, 8 siswa berada pada kategori sedang, dan 1 siswa berada pada kategori tinggi. Perolehan skor rata-rata motivasi belajar pretest 85,65 dan berada pada kategori sedang.

\section{b. Deskripsi Posttest Motivasi Belajar Siswa}

Setelah pemberian perlakukan layanan informasi menggunakan media film, maka dilakukan posttest kepada subjek penelitian, untuk mengetahui efek perlakukan. Hasil posttest motivasi belajar siswa disajikan sebagai berikut:

Tabel 2. Data Posttest Motivasi Belajar Siswa

\begin{tabular}{|l|c|l|}
\hline Subjek Penelitian & Skor & \multicolumn{1}{|c|}{$\begin{array}{c}\text { Kategori } \\
\text { Mutu }\end{array}$} \\
\hline 1. Sita & 97 & Sedang \\
2. Neily & 110 & Tinggi \\
3. Revi & 78 & Kurang \\
4. Galuh & 93 & Sedang \\
5. Resti & 116 & Tinggi \\
6. Putri & 107 & Sedang \\
7. Helda & 110 & Tinggi \\
8. Aulia & 88 & Sedang \\
9. Ahmad & 99 & Sedang \\
10. Ayu & 112 & Tinggi \\
11. Ridwan & 103 & Sedang \\
12. Berlian & 107 & Sedang \\
13. Budi & 77 & Kurang \\
14. Isma & 97 & Sedang \\
15. Rani & 116 & Tinggi \\
16. Deni & 96 & Sedang \\
17. Edi & 119 & Tinggi \\
18. Azimah & 108 & Sedang \\
19. Nensi & 107 & Sedang \\
20. Tika & 109 & Sedang \\
\hline $\mathrm{n}=$ 20 & $\sum=2 \overline{49} 9$ \\
\hline $\mathbf{2 0 4 9}=$ & \\
\hline
\end{tabular}

Hasil post-test menunjukan bahwa sebanyak 2 siswa dan berada pada kategori kurang, 12 siswa berada pada kategori sedang, 6 siswa pada kategori tinggi. Perolehen skor rata-rata motivasi belajar pada post-test 102,45 
hal ini menunjukan masuk dalam kriteria sedang, subjek yang mengalami peningkatan sebanyak 12 jika dibandingkan dengan kondisi pretest. c. Perbandingan Skor Motivasi Belajar Siswa Pretest dan Posttes

Berikut ini hasil analisis perbandingan pretest dan posttest motivasi belajar siswa:

Tabel 3. Perbandingan Skor Pre Test dan Post Test Motivasi Belajar Siswa

\begin{tabular}{|c|c|c|c|}
\hline Subjek Penelitian & Pre Test & Post Test & $\begin{array}{c}\text { Gain (d) (Post } \\
\text { Test - Pre Test) }\end{array}$ \\
\hline 1. Sita & 79 & 97 & 18 \\
\hline 2. Neily & 103 & 110 & 7 \\
\hline 3. Revi & 52 & 78 & 26 \\
\hline 4. Galuh & 79 & 93 & 14 \\
\hline 5. Resti & 108 & 116 & 8 \\
\hline 6. Putri & 85 & 107 & 22 \\
\hline 7. Helda & 102 & 110 & 8 \\
\hline 8. Aulia & 52 & 88 & 36 \\
\hline 9. Ahmad & 79 & 99 & 20 \\
\hline 10. Ayu & 108 & 112 & 4 \\
\hline 11. Ridwan & 83 & 103 & 20 \\
\hline 12. Berlian & 82 & 107 & 25 \\
\hline 13. Budi & 52 & 77 & 25 \\
\hline 14. Isma & 78 & 97 & 19 \\
\hline 15. Rani & 107 & 116 & 9 \\
\hline 16. Deni & 77 & 96 & 19 \\
\hline 17. Edi & 114 & 119 & 5 \\
\hline 18. Azimah & 83 & 108 & 25 \\
\hline 19. Nensi & 90 & 107 & 17 \\
\hline 20. Tika & 100 & 109 & 9 \\
\hline $\mathrm{n}=20$ & $\begin{aligned} \sum & =\frac{0}{1713} \\
X_{1} & =\frac{1}{20} \frac{713}{20}= \\
& 85,65\end{aligned}$ & $\begin{array}{c}\sum=\frac{0}{2049} \\
X_{2}=\frac{2}{2049}= \\
102,45\end{array}$ & $\begin{array}{l}\sum \mathrm{d}=33 \overline{6} \\
\mathrm{Md}=\frac{\Sigma d}{N}=\frac{336}{20}= \\
16,8\end{array}$ \\
\hline
\end{tabular}

Berdasarkan tabel di atas 102,45. Besarnya peningkatan skor diketahui terjadi perubahan skor rata-rata saat pretest dan posttest motivasi belajar siswa antara pretest sebesar 16,8. Hal ini menunjukkan dan posttest, skor rata-rata saat pretest sebesar 85,65 dan mengalami peningkatan saat postest yaitu sebesar bahwa ada pengaruh/ efek layanan informasi menggunakan media film terhadap motivasi belajar siswa.. 


\section{d. Uji Hipotesis}

Hipotesis penelitian yaitu:

$\mathrm{H}_{0}=$ Tidak ada pengaruh pelaksanaan layanan informasi menggunakan media film terhadap peningkatan motivasi belajar siswa

$\mathrm{H}_{1}=$ Ada pengaruh pelaksanaan layanan informasi menggunakan media film terhadap peningkatan motivasi belajar siswa

Pengujian hipotesis menggunakan uji-t, perhitungan sebagai berikut::

$t_{\text {hitung }}=\frac{M d}{\sqrt{\frac{\sum x^{2} d}{n(n-1)}}}=\frac{16,8}{\sqrt{\frac{1398}{20(20-1)}}}$ $=\frac{16,8}{1,92}=8,75$

Berdasarkan perhitungan diketahui bahwa $t_{\text {hitung }}=8,75>t_{\text {tabel }}=1,686$, dengan demikian disimpulkan bahwa tolak $\mathrm{H}_{0}$ dan terima $\mathrm{H}_{1}$ yang menyatakan ada pengaruh layanan informasi menggunakan media film terhadap peningkatan motivasi belaajr siswa.

\section{Pembahasan}

Hasil penelitian menunjukkan bahwa terdapat pengaruh pemberian layanan Informasi dengan media film terhadap motivasi belajar siswa. Hasil perhitungan menunjukkan bahwa $t_{h i t}$ sebesar 8,75 diketahui lebih besar dengan $t_{\text {tabel }}$ yaitu 1,686 . Berdasarkan hasil uji hipotesis yang telah dipaparkan diatas maka penggunaan layanan informasi dengan menggunakan media film berpengaruh dalam meningkatkan motivasi belajar siswa Penggunaan media film dalam layanan informasi terbukti mampu meningkatkan minat siswa untuk berkonsentrasi dan tertarik mengikuti layanan informasi. Munculnya minat dan daya tarik individu dalam mengikuti kegiatan adalah faktor yang sangat penting untuk mendukung tercapainya efektiftas layanan. Hal tersebut sesuai dengan pendapat Hamalik (dalam Arsyad, 2011), yaitu pemakaian media dalam layanan dapat membangkitkan keinginan dan minat yang baru, membangkitkan motivasi dan rangsangan kegiatan belajar, dan bahkan membawa pengaruh-pengaruh psikologis terhadap siswa.

$\begin{array}{lrr}\text { Motivasi } & \text { belajar } & \text { dapat } \\ \text { ditingkatkan } & \text { melalui } & \text { layanan } \\ \text { informasi. } & \text { Pelaksanaan } & \text { layanan }\end{array}$


informasi dengan menggunakan media film dapat meningkatkan motivasi belajar. Melalui media film, siswa dapat menganalisis secara visual dan dalam contoh yang lebih realisitis. Siswa bukan sekedar diberikan informasi dengan ceramah, namun mereka dapat memperoleh contohcontoh melalui pengamatan peristiwa dalam film. Hal inilah yang membuat siswa menjadi paham akan materi layanan, dan merasa kegiatan layanan informasi menjadi penting bagi mereka.Ada tiga alasan utama menurut Prayitno dan Erman (2004) mengapa pemberian informasi perlu diselenggarakan yaitu:

a. Membekali individu dengan berbagai pengetahuan tentang lingkungan yang diperlukan untuk memecahkan masalah yang dihadapi berkenaan dengan lingkugan sekitar, pendidikan, jabatan, maupun sosial budaya.

b. Memungkinkan individu dapat menentukan arah hidup apabila ia mengetahui apa yang harus dilakukan dan bagaimana bertindak secara kreatif, dinamis dan memotivasi berdasarkan atas informasi-informasi yang ada itu.

c. Setiap individu adalah unik, keunikan itu akan membawakan pola-pola pengambilan keputusan dan bertindak yang berbeda-beda disesuaikan dengan aspek-aspek kepribadian masing-masing individu.
Layanan informasi dengan menggunakan media film memiliki pengaruh terhadap motivasi belajar sehingga diharapkan tercapai hasil belajar yang optimal. Media film dapat menyentuh siswa baik secara fisik maupun secara psikis. Siswa akan tertarik dengan sajian materi layanan dengan menggunakan media film. Ketertarikan siswa terhadap media film dan media gambar berkaitan dengan keunggulankeunggulan yang ada pada media tersbut. Dengan tertarik pada media yang digunakan ini akan dapat menjadikan siswa termotivasi dalam belajar dan diharapkan dapat meningkatkan hasil belajar siswa.

Sehubungan dengan motivasi, emosional atau perasaan maka Koumi (2006) mengatakan bahwa media film dapat: merangsang keinginan belajar, membina dan memacu dalam bertindak, memotivasi suatu strategi untuk melihat keberhasilan belajar, mengurangi keterasingan siswa yang jauh, merubah sikap atau apresiasi, menyebabkan simpati yang berlebihan, menenangkan, membesarkan hati sehingga percaya diri, membuktikan abstraksi akademis. Hal tersebut didukung juag oleh 
pendapat Arsyad (2010), yang menyatakan "bahwa media berbasis visual memegang peran yang sangat penting dalam proses belajar. Agar menjadi efektif visual ditepatkan pada konteks yang bermakna dan siswa mampu berinteraksi dengan visual itu untuk menyakinkan terjadinya proses informasi”.

\section{SIMPULAN DAN SARAN}

\section{A. Simpulan}

Berdasarkan hasil analisis pengaruh pemberian layanan informasi dengan menggunakan media film dan media gambar terhadap motivasi belajar siswa yang telah diperoleh, maka dapat disimpulkan bahwa:

1. Layananan informasi yang diberikan dengan menggunakan media film berpengaruh terhadap terjadinya peningkatan motivasi siswa. Peningkatan motivasi belajar siswa setelah diberikan layanan informasi menggunakan media film yaitu sebesar 16,8

2. Penggunaan media film dalam pelaksanaan layanan informasi menghasilkan peningkatan motivasi dan minat siswa terhadap layanan informasi. Hal tersebut ditunjukkan dengan keaktifan, kesungguhan, kemauan bertanya, usaha menyelesaikan tugas, ketekukan, keuletan dan keantusiasan siswa dalam menerima layanan yang diberikan meningkat.

\section{B. Saran}

Berdasarkan hasil penelitian yang telah diperoleh, maka saran yang dapat diberikan adalah:

1. Kepada siswa

Siswa yang memiliki motivasi belajar rendah, hendaknya berusaha terus meningkatkan motivasi belajar dengan mengikuti layanan informasi sehingga tujuan belajar yang diharapkan dapat tercapai dan hasil belajar siswa lebih baik lagi.

2. Kepada guru Bimbingan dan Konseling

Layanan informasi hendaknya memanfaatkan media film untuk mencegah timbulnya permasalahan yang berkaitan dengan motivasi belajar siswa. 
64 Layanan Informasi Dengan Media Film

Penyampaian materi layanan

berbeda dalam penelitian

dengan menggunakan media

berikutnya.

yang menarik akan

Daftar Pustaka

mempermudah siswa dalam

memahami suatu informasi.

3. Untuk sekolah

Untuk meningkatkan keefektifan

layanan bimbingan dan

konseling pada siswa kiranya

disekolah melengkapi sarana

dan prasarana bimbingan dan

konseling.

4. Kepada para peneliti

Kepada para peneliti, hasil

penelitian ini hendaknya bisa

digunakan sebagai rujukan

untuk penelitian selanjutnya dan

untuk meningkatkan motivasi

belajar siswa. Dengan

menggunakan layanan,

pendekatan, dan teknik yang

sama tetapi masalah yang

\author{
A.M, Sardiman. 2010. Interaksi \& \\ Motivasi Belajar Mengajar. Jakarta : \\ PT. Rajawali Pers.
}

Arsyad, Azhar. 2011. Media Pembelajaran. Jakarta: Rajawali Pers.

Prayitno. 2004. Seri Layanan Konseling L.1-L.9. Padang: BK Fakultas Pendidikan Padang.

Prayitno dan Erman Amti. 2004. DasarDasar Bimbingan dan Konseling. Jakarta: Rineka Cipta.

Satrio, Adi. 2005. Kamus Ilmiah Populer. Visi7.

Sugiyono. 2012. Metode Penelitian Kuantitatif, Kualitatif, dan $R \& D$. Bandung: Alfabeta.

Tohirin. 2009. Bimbingan dan Konseling di Sekolah dan Madrasah (Bebasis Intergrasi). Jakarta: Raja Grafindo Persada. 